\title{
Pengelolaan Keuangan Daerah Dan Good Governance Terhadap Kinerja Satuan Kerja Perangkat Daerah
}

\author{
Saverius Dhuri Mbipi ${ }^{1}$, Prihat Assih², dan Maxion Sumtaky²
}

${ }^{1}$ Program Pasca Sarjana Universitas Merdeka Malang

Jl. Terusan Raya Dieng No. 59, Malang, 65146, Indonesia

${ }^{2}$ Fakultas Ekonomi dan Bisnis Universitas Merdeka Malang

Jl. Terusan Raya Dieng No. 62-64, Malang, 65146, Indonesia

\section{Info Artikel}

\section{Keywords:}

Accessibility; Accountability of Financial Reporting; Effectiveness of Financial Planning;

Regional Financial Management; and Transparency.

Kata Kunci:

Aksesibilitas; Akuntabilitas Pelaporan Keuangan; Efektivitas Perencanaan Keuangan; Pengelolaan Keuangan Daerah; dan Transparansi,

ISSN (print): 2598-7763 ISSN (online): 2598-7771

$\square$ Corresponding Author: Saverius Dhuri Mbipi: Tel. /Fax. +62 821-4734-4269 E-mail: saverius2504@yahoo.com

\section{Abtract}

This study aims to describe regional financial management which includes: planning and budgeting, implementation and administration and accountability of regional finances; and transparency which includes transparency and accessibility; as well as the accountability of regional financial reporting, the effectiveness of internal and external party supervision, and the performance of Regional Work Units; analyze the effect of the effectiveness of financial planning, the effectiveness of budget execution control, transparency and accountability of financial reporting on the performance of Local Government Work Units. This type of research is explanative. The number of samples in this study were 32 respondents. The data collection technique used a questionnaire. The analysis technique uses descriptive analysis and multiple linear regression analysis. Regional financial management which includes; the effectiveness of financial planning, the budget formulation process, the characteristics of the clarity of budget targets and control have an effect on the performance of regional work units. Meanwhile, transparency and accessibility of regional financial reporting and accountability of regional financial reporting have no effect on the performance of regional work units.

Citation: Mbipi, D.S, Assih, P., dan Sumtaky, M. (2020). Pengelolaan Keuangan Daerah Dan Good Governance Terhadap Kinerja Satuan Kerja Perangkat Daerah. AFRE Accounting and Financial Review. 3(2): 151-157

\section{Abstraks}

Penelitian ini bertujuan untuk mendeskripsikan pengelolaan keuangan daerah yang mencakup: perencanaan dan penganggaran, pelaksanaan dan penatausahaan dan pertanggungjawaban keuangan daerah; dan transparansi yang mencakup transparan dan aksesbilitas; serta akuntabilitas pelaporan keuangan daerah, efektivitas pengawasan pihak internal dan eksternal, dan kinerja Satuan Kerja Perangkat Daerah; menganalisis pengaruh efektivitas perencanaan keuangan, efektivitas pengendalian pelaksanaan anggaran, transparansi dan akuntabilitas pelaporan keuangan terhadap kinerja Satuan Kerja Pemerintah Daerah. Jenis penelitian yang digunakan adalah eksplanatif. Jumlah sampel dalam penelitian ini sebanyak 32 responden. Teknik pengumpulan data menggunakan kuesioner. Teknik analisis menggunakan analisis deskriptif dan analisis regresi linear berganda. Pengelolaan keuangan daerah yang mencakup; efektivitas perencanaan keuangan, proses penyusunan anggaran, karakteristik kejelasan sasaran anggaran dan pengendalian berpengaruh terhadap kinerja Satuan Kerja Perangkat Daerah. Sedangkan transparansi dan aksebilitas pelaporan keuangan daerah, dan akuntabilitas pelaporan keuangan daerah tidak berpengaruh terhadap kinerja Satuan Kerja Perangkat Daerah.

JEL Classification: G30, G32

DOI: $h$ ttps://doi.org/10.26905/afr.v3i2.5503 


\section{PENDAHULUAN}

Kota Malang pada bulan November 2019 meraih penghargaan berupa Ombudsmas Award. Ombudsman Award ini merupakan penghargaan yang diberikan oleh pemerintah pusat melalui Kementrian Dalam Negeri yakni kategori Predikat Kepatuhan Standar Pelayanan Publik 2019. Fenomena yang terjadi inilah dinilai pada aspek pengelolaan, transparansi dan akuntabilitas serta kinerja yang cukup baik.

Otonomi daerah telah membuat sentralisasi fiskal dari pemerintah pusat ke pemerintah daerah. Hal ini berdampak pada perubahan struktur keuangan di pusat maupun di daerah (Hehanussa, 2015). Pemerintah daerah hasrus mampu mengelola keuangan daerahnya untuk peningkatan kesejahteraan masyarakat.

Pemerintah daerah harus mampu mengelola keuangan dengan baik. Keuangan daerah dikelola dengan sesuai peraturan yang berlaku, dikelola secara tertif, efisien dan efektif, transparan, ekonomi dan bertangung jawab. Asaz dalam pengelolaan keuangan daerah yaitu kepatutan, keadilan, dan manfaat untuk masyarakat (Raharja et al., 2017 dan Bolang et al., 2013). Implementasi Good Corporate Governance dalam pengelolaan keuangan daerah akan mampu menciptakan akuntabel dan transparan.

Pengawasan yang dilakukan oleh inspektorat secara internal yang semakin kuat dan Badan Badan Pemeriksa Keuangan (BPK) membuat pengelolaan keuangan daerah menjadi sangat penting. Selain itu, pemerintah daerah telah banyak mendapat sorotan karena maraknya pemberian opini dari BPK tentang pengelolaan keuangan pemerintah daerah (Bolang et al., 2013; Safwan et al., 2013; dan Tarigan \& Nurtanzila, 2013).

Faktor yang mempengaruhi kinerja pemerintah daerah adalah pengelolaan keuangan daerah (Auditya et al., 2013; Pujiono et al., 2016; Ridzal, 2020; Defitri, 2018; dan Nasution, 2018). Dalam rangka mewujudkan tata kelola pemerintahan yang baik, pemerintah terus melakukan berbagai upaya perbaikan untuk meningkatkan transparansi dan akuntabilitas pengelolaan keuangan daerah, salah satunya dengan penyempurnaan sistem administrasi negara secara menyeluruh (LAN 2000). Salah satu cara yang ditempuh peme- rintah dengan menerbitkan dan menyempurnakan perangkat peraturan perundangan tentang pengelolaan keuangan negara/ daerah (Sulistyo, 2018; Istiqomah, 2018; Fara et al., 2018; Annisa, 2017; dan Rohman, 2007).

Pengelolaan keuangan pemerintah Kota Malang pada tahun 2016-2018 berdasarkan hasil pemeriksaan BPK RI telah berhasil meraih penilaian opini Wajar Tanpa Pengecualian (WTP) dari tahun 2016-2018 (Rohmah et al., 2020). Pencapaian opini Wajar Tanpa Pengecualian merupakan bentuk dukungan adanya Good governance and Clean Government dengan pengelolaan keuangan daerah yang transparan dan akuntable (Wulandari \& Bandi, 2015).

Hasil penelitian menunjukkan bahwa pengelolaan keuangan daerah berpengaruh terhadap kinerja keuangan daerah (Hendra, 2018; dan Kartoprawiro \& Susanto, 2018). Selain itu tata Kelola keuangan daerah yang transparansi dan akuntabilitas publik akan berpengaruh terhadap kinerja keuangan daerah (Budiati et al., 2020; Anggiriawan \& Kawisana, 2020; Indriana \& Nasrun, 2019; Muslih et al., 2019; dan Maramis et al., 2018).

Penelitian ini bertujuan untuk: 1) menganalisis pengaruh Pengelolaan Keuangan Daerah terhadap Kinerja Satuan Kerja Perangkat Daerah; 2) menganalisis pengaruh transparansi Pelaporan Keungan Daerah terhadap Kinerja Satuan Kerja Perangkat Daerah; dan 3) menganalisis pengaruh akuntabilitas Pelaporan Keuangan Daerah terhadap Kinerja Satuan Kerja Perangkat Daerah.

\section{PENGEMBANGAN HIPOTESIS}

\section{Pengelolaan Keuangan Daerah dan Kinerja Satuan Kerja Perangkat Daerah}

Pengelolaan keuangan daerah merupakan kegiatan yang dijalankan oleh pejabat pengelola keuangan daerah sesuai dengan kedudukan dan kewenangannya yang didalamnya mencakup; perencanaan dan penganggaran, pelaksaan dan penatausahaan, pengawasan dan pertanggungjawaban. keuangan daerah pada intinya mencangkup dua hal, yaitu Hak Daerah dan Kewajiban Daerah. Hak daerah ialah segala hal yang secara hukum merupakan milik daerah dan dapat dijadikan sebagai milik pemerintah. Sedangkan kewajiban adalah sesuatu yang ha- 
rus dilaksanakan atau dikerjakan, ataupun hal-hal yang berkaitan dengan tugas dan pekerjaan. Jika hak dan kewajiban tersebut dapat dinilai dengan uang, maka hal tersebut telah dapat dikatakan sebagai bagian dari keuangan daerah.

Transparansi adalah memberikan informasi keuangan yang terbuka dan jujur kepada masyarakat berdasarkan pertimbangan bahwa masyarakat memiliki hak untuk mengetahui secara terbuka dan menyeluruh atas pertanggungjawaban pemerintah dalam pengelolaan sumber daya yang dipercayakan kepadanya dan ketaatannya pada peraturan perundang-undangan. Dalam Peraturan Pemerintah Nomor 58 tentang Pengelolaan Keuangan Daerah, dinyatakan bahwa keuangan daerah harus dikelola secara tertib, taat pada peraturan perundang-undangan, efisien, ekonomis, efektif, transparan, dan bertanggungjawab dengan memperhatikan asas keadilan, kepatuhan, dan manfaat untuk masyarakat. Disamping itu, dengan meningkatkan transparansi pengelolaan keuangan daerah maka diharapkan kualitas pelayanan public akan semakin baik dan akan terwujud tata kelola pemerintahan yang baik dan pemeritahan yang bersih (good governance governance dan clean government).

Kinerja merupakan salah satu bentuk perpaduan antara kemampuan dan usaha untuk memperoleh hasil dari suatu pekerjaan. Untuk mencapai hasil yang baik, seseorang hendaknya memiliki keinginan dan kemampuan, usaha serta bentuk kegiatan yang dilaksanakan dan tidak mengalami hambatan yang berarti di dalam melaksanakan suatu pekerjaan. Dalam konteks pemerintahan, kinerja akan dinilai sebagai suatu prestasi manakala dalam melaksanakan suatu kegiatan dilakukan dengan mendasarkan pada peraturan yang berlaku, tidak melangar hukum dan sesuai dengan moral dan etika (Yusriati, 2008).

Akuntabilitas merupakan mempertang-gungjawabkan pengelolaan sumber daya serta pelaksanaan kebijakan yang dipercayakan kepada entitas pelaporan dalam mencapai tujuan yang telah ditetapkan secara periodik. Implementasi konsep akuntabilitas dilakukan dengan pemeriksaan (audit) secara berkala atas laporan keuangan yang ditertibkan oleh pejabat/pengurus lembaga publik. Namun tentu saja hasil dari pemeriksaan (audit) tidak akan mampu mengungkap seluruh penyimpangan yang terjadi, karena hal ini sangat tergantung pada banyak faktor. Adanya audit yang komprehensif, setidaknya penyimpangan-penyimpangan tersebut dapat diungkap dan dicarikan jalan keluar yang terbaik.

Prinsip pengelolaan keuangan ialah efektif dan efisiensi yang mana pengeluran anggaran daerah didasarkan pada proporsi kebutuhan program dan kegiatan daerah guna menghasilkan output ataupun income tanpa mengurangi pelayanan yang maksimal pada masyarakat. Penelitian Solina (2014) menunjukkan bahwa Akuntabilitas publik, partisispasi anggaran dan kejelasan sasaran anggaran berpengaruh signifikan terhadap kinerja manajerial SKPD di Kota Tanjung Pinang.

$\mathrm{H}_{1}$ : Pengelolaan Keuangan Daerah berpengaruh positif terhadap Kinerja Satuan Kerja Perangkat Daerah

Transparansi Pelaporan Keuangan Daerah dan Kinerja Satuan Kerja Perangkat Daerah Kota Malang

Penyelengaraan pemerintahan yang transparan akan memiliki adanya pertanggungjawaban terbuka, adanya aksesibilitas terhadap laporan keuangan, adanya publikasi laporan keuangan, hak untuk tahu hasil audit dan ketersediaan informasi kinerja. Dalam hal pelaksanaan transparansi pemerintah, media masa mempunyai peranan yang sangat penting, baik sebagai sebuah kesempatan untuk berkomunikasi pada publik maupun menjelaskan berbagai informasi yang relevan, juga sebagai penonton atas berbagai aksi pemerintah dan prilaku menyimpang dari aparat birokrasi. Friyanti (2016) dalam penelitian ini menemukan bahwa Partisipasi penyusunan anggaran, transparansi laporan keuangan, kejelasan anggaran, umpan balik, evaluasi anggaran dan sistem pengendalian pemerintahan berpengaruh positif dan signifikan terhadap kinerja manajerial aparat pemerintahan daerah Indramayu.

$\mathrm{H}_{2}$ : Transparansi Pelaporan Keungan Daerah berpengaruh terhadap Kinerja Satuan Kerja Perangkat Daerah

Akuntabilitas Pelaporan Keuangan Daerah dan Kinerja Satuan Kerja Perangkat Daerah

Akuntabilitas pengelolaan keuangan 
daerah merupakan proses pengelolaan keuangan daerah mulai dari perencanaan, pelaksanaan, penatausahaan, pertanggungjawaban, serta pengawasan harus benar-benar dapat dilaporkan dan dipertanggungjawabkan kepada masyarakat dan DPRD terkait dengan kegagalan maupun keberhasilannya sebagai bahan evaluasi tahun berikutnya. Mulyani (2016) dalam penelitian menemukan bahwa secara simultan akuntabilitas publik, partisipasi penyusunan anggaran, kejelasan anggaran, struktus desentralisasi, sistem pengukuran kinerja, kompensasi, etika kerja dan komitmen profesional berpengaruh positif dan signifikan terhadap kinerja manajer di dinas Kabupaten Kampar.

$\mathrm{H}_{3}$ : Akuntabilitas Pelaporan Keuangan Daerah berpengaruh terhadap Kinerja Satuan Kerja Perangkat Daerah.

\section{DATA DAN METODE}

Desain penelitian ini adalah penelitian kausalitas. Penelitian kausalitas bertujuan untuk menjelaskan sebab-akibat antar variabel (Anwar, 2016). Metode yang digunakan dalam mengumpulkan data dengan cara survei secara langsung kepada responden untuk

Tabel 1. Hasil Regresi

\begin{tabular}{lllll}
\hline & Koefisien & Std. Error & $\mathrm{t}_{\text {hit }}$ & Prob. \\
\hline (Constant) & 10,382 & 3,455 & 3,005 & 0,006 \\
Pengelolaan Keuangan & 0,286 & 0,094 & 3,039 & 0,005 \\
Transparansi & $-0,069$ & 0,138 & $-0,500$ & 0,621 \\
Akuntabilitas & 0,189 & 0,253 & 0,749 & 0,460 \\
F $_{\text {hit }}$ & 5,875 & & & \\
$F_{\text {Prob }}$ & 0,003 & & & \\
\hline
\end{tabular}

Berdasarkan hasil analisis goodness fit of model menunjukkan bahwa model yang digunakan baik. Hal ini ditunjukkan dengan dari probabilitas nilai F sebesar 0,003. Berdasarkan hasil analisis regersi menunjukkan pengelolaan keuangan daerah berpengaruh positif terhadap Kinerja Satuan Kerja Perangkat Daerah. Sedangkan transparansi dan akuntabilitas tidak berpengaruh terhadap Kinerja satuan Satuan Kerja Perangkat Daerah. Sedangkan pengelolaan keuangan daerah berpengaruh positif terhadap Kinerja Satuan Kerja Perangkat Daerah. mendapatkan informasi dan menarik kesimpulan.

Populasi pada penelitian ini adalah Satuan Kerja Perangkat Daerah Kota Malang yang mencakup dinas dan badan serta Dewan Perwakilan Daerah Kota Malang yang berjumlah 36 SKPD. Teknik pengumpulan data dengan kuesioner. Teknik Analisis Data yang digunakan dalam penelitian ini adalah Regresi Linear Berganda. Persamaan regresi linear berganda pada penelitian ini dirumuskan sebagai berikut:

$$
Y=\alpha+\beta_{1} X_{1}+\beta_{2} X_{2}+\beta_{3} X_{3} e
$$

Dimana: $Y=$ Kinerja Satuan Kerja Perangkat Daerah; $\alpha=$ Konstan, $\beta_{1}, \beta_{2}, \beta_{3}=$ Koefisien regresi, $X_{1}=$ Pengelelolaan Keuangan; $X_{2}=$ Transparansi; $X_{3}=$ Akuntabilitas dan $\mathrm{e}=$ Error

\section{HASIL}

Hasil analisis regresi dilakukan untuk mengetahui seja-uh mana pengaruh variabel dependen ter-hadap variabel independen. Pengaruh ini dilihat dari kenaikan satu poin variabel independen maka variabel dependen akan naik sejumlah nilai Beta. Hasil analisis regersi disajikan pada tabel 1 .

\section{PEMBAHASAN}

\section{Pengelolaan Keuangan Daerah terhadap Kinerja Satuan Kerja Perangkat Daerah}

Hasil penelitian menunjukkan bahwa pengelolaan keuangan daerah berpengaruh positif terhadap Kinerja satuan kerja perangkat ldaerah pemerintah Kota Malang. Hal ini menunjukkan bahwa Satuan Kerja Perangkat Daerah telah menyusun perencanaan baik rencana pembangunan jangka menengah 5 tahun, yang di dalamnya telah dirumuskan visi misi secara jelas. Selain itu SKPD juga telah menyusun rencana operasional sebagai 
basis penyusunan program, kegiatan dan anggaran tahun berjalan. Penyusunan rencana lpembangunan ljangka menengah dan rencana pembangunan tahunan merupakan perwujudan dari pemenuhan kebutuhan pelayanan masyarakat secara bertahap dan berkesinambungan yang disesuaikan dengan kemampuan sumber-sumber pendapatan daerah tiap periode tahun anggaran. Pengelolaan keuangan yang tercermin dalam rencana kerja dan anggaran, berfungsi sebagai standar kinerja masing-masing SKPD. Salah satu indikator pengukuran kinerja adalah tingkat penyerapan anggaran dimana dalam llaporan realisasi anggaran, terdapat perbandinganl antara anggaran dan lrealisasi, sehingga pemangku jabatan dalam hal ini lpihak eksekutif akan berupaya melaksanakan program, kegiatan dan langgaran yang ltelah ditetapkan. Dengan demikian pengelolaan berpengaruh terhadap lkinerja SKPD.

Transparansi Pelaporan Keungan Dae-rah terhadap Kinerja Satuan Kerja Perangkat Daerah

Hasil penelitian menunjukkan bahwa transparansi pelaporan keuangan tidak berpengaruh terhadap kinerja Satuan Kerja Perangkat Daerah. Transparansi laporan keuangan berdasarkan hasil pengujian tidak berpengaruh terhadap kinerja SKPD. Akan tetapi dalam teori bahwa transparansi berpengaruh terhadap kinerja. Transparansi ladalah kebebasan untuk mengakses linformasi lyang dibutuhkan lberkaitan ldengan kepentinganl publikl yang lsecara llangsung dapat diperoleh loleh pihak-pihak lyang bekepentingan. Penerapan asas transpa-ransi mencakup kemudahan mengakses informasi keuangan yang dibutuhkan masyarakat, dan laporan tersebut dapat dipahami. Kemudahan mengakses informasi terwujud apabila dipublikasikan secara terbuka melalui media masa atau website. Akan tetapi dalam penelitian ini peneliti mendapat respon dari responden bahwa tranparansi tidak berpengaruh terhadap pencapaian kinerja satuan kerja perangkat daerah, berarti pelaksanaan tanggung jawab pemerintah daerah melalui SKPD masing-masing, menyusun laporan keuangan yang diungkapkan tidak jujur dan tidak terbuka memungkinkan semua pihak yang berkepentingan terutama masyarakat tidak me-ngetahui sekaligus tidak dapat menilai perkembangan alokasi sumber-sumber pendapatan daerah oleh masing-masing SKPD.

\section{Akuntabilitas Pelaporan Keuangan Daerah terhadap Kinerja Satuan Kerja Perangkat Daerah}

Hasil penelitian menunjukkan bahwa akuntabilitas pelaporan keuangan tidak berpengaruh terhadap kinerja Satuan Kerja Perangkat Daerah. Sementara dalam teori akuntabilitas berpengaruh terhadap kinerja SKPD dimana masyarakat mempunyai hak untuk mengetahui segala informasi atau kebijakan yang dikeluarkan oleh pemerintah setempat dan pemerintah mempunyai kewajiban untuk menyediakan atau memberikan informasi secara terbuka kepada masyarakat pada umumnya. Sementara akuntabilitas merupakan kewajiban seseorang atau organisasi untuk melaksanakan tanggung jawabnya. Di samping itu aspek akuntabilitas termasuk kejujuran menyajikan transaksi informasi keuangan yang seharusnya disajikan, dan dapat dibandingkan dengan indikator kinerja serta dapat digunakan untuk tindakan koreksi.

\section{SIMPULAN DAN SARAN}

Berdasarkan hasil dan pembahasan menunjukkan bahwa Pengelolaan Keuangan Daerah berpengaruh terhadap kinerja Satuan Kerja Perangkat Daerah Kota Malang. Hal ini menunjukkan penerapan pengelolaan keuangan secara efektif, semua fungsi manajemen tata kelola keuangan telah diterapkan secara efektif. Namun Transparansi dan akuntabilitas pelaporan keuangan tidak berpengaruh terhadap kinerja Satuan Kerja Perangkat Daerah. Artinya sistem transparansi dan akuntabilitas dalam pelaporan keuangan daerah sudah menjadi kewajiban pemerintah sebagai perwujudan good governance governance dan clean government.

Dalam pengumpulan data penelitian ini ada beberapa kendala, yaitu ada beberapa SKPD yang tutup sementara karena masa pandemi COVID, sehingga komunikasi yang dilakukan kepada pimpinan SKPD menjadi terbatas. Selain itu pengukuran kepuasan masyarakat terhadap kinerja SKPD, adalah berdasarkan persepsi pimpinan SKPD, bukan persepsi langsung dari masyarakat sebagai penerima pelayanan. Untuk penelitian selanjutnya diharapkan untuk menambahkan var- 
iable lain dan juga dan memperluas lokasi penelitian.

\section{DAFTAR PUSTAKA}

Anggiriawan, P. B., \& Kawisana, P. G. W. P. (2020). Pengaruh Prinsip-Prinsip Good Corporate Governance pada Kinerja Keuangan Lembaga Perkreditan Desa. E-Jurnal Akuntansi, 30(9), 2281. https://doi.org/10.24843/eja.2020.v30.i 09.p09

Annisa, V. (2017). Pengaruh Sistem Akuntansi Keuangan Daerah, Pengelolaan Keuangan Daerah, Dan Good Governance Terhadap Kinerja Pemerintah Daerah. JOMFekom, 4(1), 843-857.

https://media.neliti.com/media/public ations/125589-ID-analisis-dampakpemekaran-daerah-ditinja.pdf

Anwar, S. (2016). Metodologi Penelitian Bisnis. Jakarta: Salemba Empat. In IOSR Journal of Economics and Finance.

Auditya, L., Husaini, \& Lismawati. (2013). Analisis Pengaruh Akuntabilitas Dan Transparansi Pengelolaan Anggaran Pendapatan. Jurnal Fairness, 3(1), 21-41.

Bolang, M. S., Sondakh, J. J., \& Morasa, J. (2013). Pengaruh Kompetensi, Independensi Dan Pengalaman Terhadap Kualitas Audit Aparat Inspektorat Kota Tomohon Dalam Pengawasan Pengelolaan Keuangan Daerah. Accountability, 2(1), 151. https://doi.org/10.32400/ja.2352.2.1.20 13.151-163

Budiati, Y., Sugiyanto, E. K., \& Niati, A. (2020). Pengaruh Gcg Terhadap Kinerja Pengelolaan Dana Desa Dengan Moderasi Sistem Pengendalian Internal. EKUITAS (Jurnal Ekonomi Dan Keuangan), 3(4), 425-444. https://doi.org/10.24034/j25485024.y20 19.v3.i4.4127

Defitri, S. Y. (2018). Pengaruh Pengelolaan Keuangan Daerah Dan Sistem Akuntansi Keuangan Daerah Terhadap Kualitas Laporan Keuangan Pemerintah Daerah. Jurnal Benefita, 3(1), 64. https://doi.org/10.22216/jbe.v3i1.2376

Fara, N., Soleman, R., \& Hormati, A. (2018). Pengaruh Pengendalian Intern dan Pengelolaan Keuangan Daerah dengan
Komitmen Organisasi sebagai Variabel Moderasi. Jurnal Riset Akuntansi, 5(2), 74-89.

Hehanussa, S. J. (2015). Pengaruh Penyajian Laporan Keuangan Daerah Dan Aksesibility Laporan Keuangan Daerah Terhadap Transparansi Dan Akuntabilitas Pengelolaan Keuangan Daerah Kota Ambon. Conference in Busniess, Accounting and Management, 2(1), 82-90.

Hendra, J. (2018). Pengaruh partisispasi dalam penganggaran dan peran manajerial pengelola keuangan daerah terhadap kinerja pemerintah daerah. Jurnal Ilmiah Ilmu Akuntansi, Keuangan Dan Pajak E ..., 2(1), 8-17. https://core.ac.uk/download/pdf/229 363812.pdf

Indriana, I., \& Nasrun, M. (2019). Pengaruh Good Corporate Governance Terhadap Kinerja Keuangan Pemerintah daerah Kabupaten Pankajene Dan Kepulauan. Equilibrium, 8(1), 19-26.

Kartoprawiro, S., \& Susanto, Y. (2018). Analisis Terhadap Kinerja Laporan Keuangan Pemerintah Daerah Kabupaten Musi Rawas. Jurnal Manajemen Dan Bisnis Sriwijaya, 16(1), 114. https://doi.org/10.29259/jmbs.v16i1.62 42

Lembaga Administrasi Negara 2003. Pedoman Penyusunan Pelaporan Akuntabilitas Kinerja Instansi Pemerintah. Jakarta: Diterbitkan oleh LAN.

Maramis, M. M., Morasa, J., \& Wokas, H. R. N. (2018). Pengaruh Penerapan Good Governance Dan Sistem Akuntansi Keuangan Terhadap Kualitas Laporan Keuangan Pada Pemerintah Kota Manado. Going Concern: Jurnal Riset Akuntansi, 13(04), 563-570. https://doi.org/10.32400/gc.13.03.2068 5.2018

Muslih, O., Rahadi, D. R., \& Marbun, S. O. (2019). Tata Kelola Pemerintahan Berkelanjutan Untuk Meningkatkan Kinerja Pemerintah Daerah Sustainable Governance for Enhancing Local Government Performance. Konferensi Nasional Ilmu Administrasi, 1-7.

Nasution, D. A. D. (2018). Analisis Pengaruh Pengelolaan Keuangan Daerah, 
Akuntabilitas dan Transparansi terhadap Kinerja Keuangan Pemerintah. Jurnal Studi Akuntansi \& Keuangan, 2(3), 149-162.

https://ejurnal.id/index.php/jsak/issu e/view $/ 26$

Pujiono, D. S., Sukarno, H., \& Puspitasari, N. (2016). Pengaruh Sistem Pengendalian Intern Terhadap Pengelolaan Keuangan Daerah Serta Kinerja Pemerintah Daerah (Studi di Provinsi Maluku Utara). Jurnal Bisnis Dan Manajemen, 10(1), 68-81.

Raharja, M., Pratiwi, R. N., \& Wachid, A. (2017). Pengelolaan Keuangan dan Aset Daerah ( Studi pada Badan Pengelolaan Keuangan dan Aset Daerah, Kabupaten Lamongan ). Jurnal Administrasi Publik (JAP), Universitas Brawijaya, Malang, 3(1), 111-117.

Ridzal, N. A. (2020). Pengaruh Kualitas Laporan Keuangan Terhadap Akuntabilitas Kinerja Pada Badan Pengelolaan Keuangan Dan Aset Daerah (Bpkad) Kabupaten Buton. Financial: Jurnal Akuntansi, 6(1), 87-97. https://doi.org/10.37403/financial.v6i1 .135

Rohmah, L., Noor Shodiq Askandar, \& Sari, A. F. K. (2020). Pengaruh Pemahaman Standar Akuntansi Pemerintah, Pemanfaatan Sistem Informasi Akuntansi Keuangan Daerah Dan Sistem Pengendalian Internal Terhadap Kualitas Laporan Keuangan Pemerintah Daerah Kota Malang. E-Jra, 09(02), 4757.

Safwan, Nadirsyah, \& Abdullah, S. (2013). Pengaruh Kompetensi Dan Motivasi Terhadap Kinerja Pengelolaan Keuangan Daerah Pada Pemerintah Daerah Kabupaten Pidie Jaya. Pascasarjana Universitas Syiah Kuala, 7(1), 133.

Sulistyo, A. T. (2018). Analisis Kinerja Keuangan Pemerintah Provinsi Kalimantan Timur. Indonesian Treasury Review Jurnal Perbendaharaan Keuangan Negara Dan Kebijakan Publik, 3(1), 43-59. https://doi.org/10.33105/itrev.v3i1.22

Tahar, A., Aditya Prayoga Akuntansi, M., \& Muhammadiyah Yogyakarta, U. (2021). Pengaruh Tata Kelola Publik, Intergovernmental Revenue, dan Kompetensi terhadap Kinerja Pemerintah Daerah (Studi Empiris pada Organisasi Perangkat Daerah di Kabupaten Lombok Timur). Jurnal Akuntansi AKUNESA, 9(2). https://journal.unesa.ac.id/index.php/ akunesa

Tarigan, E. P. A., \& Nurtanzila, L. (2013). Standar Akuntansi Pemerintahan dalam Mewujudkan Akuntabilitas dan Transparansi Pengelolaan Keuangan Daerah. JKAP (Jurnal Kebijakan Dan Administrasi Publik), 17(1), 29-45. https://doi.org/10.22146/jkap.6847

Wulandari, I., \& Bandi, B. (2015). Pengaruh EGovernment, Kapabilitas Apip Dan Persentasi Penyelesaian Tindak Lanjut Terhadap Opini Audit Laporan Keuangan Pemerintah Daerah Di Indonesia. Jurnal Akuntansi Dan Bisnis, 15(2), 148. https://doi.org/10.20961/jab.v15i2.184

Undang-undang No. 22/1999 yang direvisi UU No. 32/2004 tentang Pemerintah Daerah.

Undang-undang No. 25/1999 yang direvisi menjadi UU No. 32/2004 tentang Perimbangan Keuangan Antara Pusat dan Daerah. www.hukumonline.com

Undang-undang No. 25/2004 tentang system Perencanaan Pembangunan Nasional (SPPN). 